\title{
ТЕНДЕНЦІЇ МОВНОЇ ПОЛІТИКИ УКРАЇНИ В РЕАЛІЯХ ВЛАДИ ПРЕЗИДЕНТА ВОЛОДИМИРА ЗЕЛЕНСЬКОГО ТА ПАРЛАМЕНТСЬКОЇ МОНОБІЛЬШОСТІ «СЛУГИ НАРОДУ»
}

\section{Шумицька Г. В., Путрашик В. I.}

\section{ВСТУП}

У цій публікації продовжуємо спостереження за тенденціями мовної політики в Україні в розрізі дотичних внутрішньодержавних i міжнародних подій, зокрема на основі відображення їх у новинних інтернет-медіа. У попередніх наших статтях на цю тему ${ }^{1}$ охоплено період від вересня 2017 р., коли було ухвалено Закон «Про освіту», мовна стаття якого стала предметом гострих дискусій як усередині України, так і за кордоном, і до кінця літа 2019 р. - часу завершення позачергового парламентського виборчого марафону й формування Верховної Ради 9-го скликання.

Нагадаємо, перше урочисте засідання новообраного законодавчого органу України відбулося 29 серпня 2019 р. Упродовж нього було сформовано т. зв. монобільшість із фракції «Слуга народу», обрано нового Голову ВР, Прем'єр-міністра, уряд, Генерального прокурора тощо 2 .

1 Шумицька Г.В. Через діалог до взаєморозуміння в мультилінгвальному просторі: регіональна рецепція мовних новацій в освітній сфері. Монографія. Ужгород : Гражда, 2019. 104 с.; Шумицька Г., Путрашик В. Мовне законодавство України в проєкціях онлайнового медіапростору Закарпаття. Науковий вісник Ужггородського університету. Серія: Філологія. 2019. Випуск 2 (42). С. 118-129; Шумицька Г., Путрашик В. Мовне питання в Україні після висновків Венеційської комісії: закарпатський онлайновий медіаракурс. Таврійські філологічні наукові читання : Матеріали міжнародної науково-практичної конференції, м. Київ, 26-27 січня 2018 p. Київ : Таврійський національний університет імені B.I. Вернадського, 2018. С. 188-193; Шумицька Г., Путрашик В. Новинні сайти як індикатор мовної ситуації в Україні (на прикладі вебресурсів Закарпаття). Стиль $i$ текст. Науковий збірник. 2017. Випуск 1 (17). С. 163-180; Шумицька Г., Путрашик В. Реакція медіа на статтю 7 Закону «Про освіту» як віддзеркалення сучасної мовної ситуації в Україні (на матеріалах новинних вебресурсів Закарпаття). Науковий потенціал та перспективи розвитку філологічних наук : Матеріали міжнародної науково-практичної конференції, м. Київ, 8-9 грудня 2017 р. Київ : Таврійський національний університет імені В.І. Вернадського, 2017. С. 174-178.

${ }^{2}$ Відбулася перша сесія Верховної Ради України IX скликання (відео). Верховна Рада Украӥни: офіиійний вебпортал. URL: https://www.rada.gov.ua/news/Novyny/ 179613.html. (Дата публікації: 30.08.2019. Дата звернення: 20.04.2020) 
Таким чином, від цього часу в обраного у квітні 2019 р. Президента України Володимира Зеленського з'явилася змога фактично безперешкодно втілювати задеклароване під час виборчого періоду власне бачення дальшого руху держави 3 максимальною підтримкою на законодавчому та виконавчому рівнях влади, зокрема й силового блоку.

Для нас цікавими $\epsilon$, передусім, спрямування мовнополітичного курсу за нового керівництва України від вересня 2019 р. до часу написання статті (кінець квітня 2020 р).

\section{1. Штрихи до мовної ситуації}

\section{в новітній суспільно-політичній парадигмі України}

Початок роботи Верховної Ради одразу ознаменувався навколомовними суперечками. Так, співголова фракції "Опозиційна платформа - «За життя»" (далі - ОПЗЖ) Вадим Рабінович під час засідання Комітету ВР із питань прав людини, деокупації та реінтеграції 4 вересня 2019 р. замість державної мови принципово використовував російську, мотивуючи свій вибір тим, що так йому, мовляв, простіше висловлювати думки. Голова названого Комітету Дмитро Лубінець нагадав колезі про вимогу закону виступати українською: «Я дуже прошу на засіданнях комітету, при всій моїи повазі до вас, Вадиме Зіновійовичу, і російськомовних вибориів, яких так само і я представляю, бо я мажоритарник із Донецької області, не порушувати закони Украӥни». Рабінович обурився і пообіцяв звернутися 3 цього приводу до Конституційного Суду ${ }^{3}$. Утім такий демарш новообраного депутата 3 ОПЗЖ був уже не перший $\mathrm{i}$, як виявилося, не останній. За три тижні до цього на засіданні підготовчої депутатської групи аналогічне зауваження щодо виступів Рабіновича російською мовою йому зробила й народна депутатка 3 фракції «Європейська солідарність» Ірина Геращенко, а лідер партії «Слуга народу» (пізніше - Голова ВР) Дмитро Разумков, який вів зібрання, підтримав колегиню, заявивши, що виступи парламентарів українською мовою передбачені законом про регламент Верховної Ради. У відповідь - суперечки й безапеляційне твердження, мовляв, «давайте жити за законами - в законах цього не сказано» ${ }^{4}$.

\footnotetext{
${ }^{3}$ Рабіновичу нагадали про необхідність виступати у Раді українською. Укрінформ. URL: https://www.ukrinform.ua/rubric-polytics/2773283-rabinovicu-nagadali-pro-neobhidnistvistupati-u-radi-ukrainskou.html. (Дата публікації: 04.09.2019. Дата звернення: 25.04.2020)

${ }^{4}$ Рабінович відмовився переходити на українську. Після зауваження Геращенко, Разумков пригрозив вимикати мікрофон (ВIДЕО). Tексти.org.ua. URL: https://texty.org.ua/fragments/95819/Rabinovych_vidmovyvsa_perehodyty_na_ ukrajinsku_ Pisla_zauvazhenna-95819. (Дата звернення: 21.04.2020)
} 
5 вересня під час засідання Нацради 3 питань телебачення і радіомовлення Рабінович знову відмовився виступати державною мовою, заявивши, що нібито «закон («Про забезпечення функціонування української мови як державної» - Ред.) не поширюється на народних депутатів». Це викликало невдоволення присутніх. Між ним та іншими учасниками зібрання сталася словесна перепалка, до якої долучився ще один народний депутат від ОПЗЖ Олег Волошин, котрий ще під час перерви у фоє поштовхався 3 активістами 5 . Власне, таку поведінку нардепів від ОПЗЖ цілком можна трактувати як спекулювання на почуттях частини російськомовних виборців, не відкидаючи й підігрування московським бажанням дестабілізації ситуації в Україні. Крім того, не виключено, що це ще й один зі способів перевірки реакції соціуму, а також (можливо, й насамперед) владних гілок, у нових суспільно-політичних реаліях.

Чималий інтерес представників громадянського суспільства до 3'ясування того, який же курс у завжди болісному для України мовному питанні обере Зе-команда, здобувши керівні щаблі, значно підігрівало мляве контактування нової влади з медіа, а то й відверте небажання це робити, що супроводжувалося навіть заявами про непотрібність журналістики як такої. Отже, занепокоєння стосовно долі ухваленого у квітні 2019 р. мовного закону тільки зростала.

4 вересня 2019 р. в Секретаріаті Уповноваженого ВРУ 3 прав людини, відповідно до Закону України «Про забезпечення функціонування української мови як державної», відбувся відкритий конкурс на посаду Уповноваженого із захисту державної мови. Конкурсна комісія більшістю голосів рекомендувала для подання Кабінету Міністрів України кандидатуру Тараса Креміня ${ }^{6}$, який $\epsilon$ співавтором законів «Про освіту», «Про фахову передвищу освіту», «Про повну загальну середню освіту», а також «Про забезпечення функціонування української мови як державної». Однак щойно створений Кабінет Міністрів на чолі з О. Гончаруком цей висновок проігнорував. Такий поворот, звичайно, не додав упевненості захисникам державної мови та обстоювачам неухильного дотримання вимог відповідного закону. А коли минув останній термін призначення

5 Рабінович відмовився виступати в Нацраді українською, що призвело до конфлікту. Інтерфакс. URL: https://www.ukrinform.ua/rubric-society/2773831rabinovic-vidmovivsa-vistupati-v-nacradi-ukrainskou-u-zasidanni-pererva.html. (Дата звернення: 25.04.2020)

6 Уповноваженим із захисту державної мови обраний Тарас Кремінь омбудсмен. Детектор медіa. URL: https://detector.media/community/article/170468/ 2019-09-04-upovnovazhenim-iz-zakhistu-derzhavnoi-movi-obranii-taras-kreminombudsmen (Дата звернення: 25.04.2020) 
Уповноваженого 3 питань державної мови, а отже, i створення інституції, яка мала б контролювати виконання мовного закону, громадський діяч Андрій Смолій 17 жовтня 2019 р. із цього приводу пише: "Де-факто відбувається повний саботаж із боку нової влади реалізації мовної політики в Україні. Закон є, а реальне виконання його норм намагаються затягнути. Цілком імовірно, ие відбувається у зв'язку з планами «Слуги народу» внести зміни до мовного законодавства та знівелювати норми мовного закону в бік їх послаблення, на догоду «русскому міру». Зрештою, влада повинна наразі дати відповіді, чи буде в повній мірі реалізовуватись мовний закон і коли будуть закладені кошти на розвиток державної мови в силу виконання Закону» ${ }^{7}$.

Разом із тим 6 листопада, відповідно до вимог згаданого мовного закону, Кабінет Міністрів України створив Національну комісію зі стандартів державної мови, яка також покликана перевіряти рівень володіння державною мовою тих, хто прагне набути громадянства України чи посісти визначені законом посади ${ }^{8}$.

А 27 листопада 2019 р. першу в історії України мовну омбудсменку таки було призначено: нею стала Тетяна Монахова - докторка філологічних наук, завідувачка кафедри журналістики Чорноморського національного університету ім. Петра Могили. Як зазначила сама пані Монахова, вона хотіла б стати, насамперед, адвокатом мовного закону, зняти проти нього упередження деякої частини громадян, яку просто залякали. Для таких людей потрібне чітке роз'яснення суті документа. Зміну ставлення до державної мови омбудсменка бачить в іiі популяризації, позбавленні населення від упереджень, негативних стереотипів тощо. «Ми будемо до них звертатися, оскільки я вважаю, що популяризація - це теж форма захисту», - наголосила уповноважена 9 .

А основне своє завдання на посаді Тетяна Монахова вбачає у забезпеченні права громадян України на здобуття інформації та послуг державною мовою, вважаючи останню інструментом залучення людини в суспільство. Адже завдяки державній мові громадянин має

${ }^{7}$ Уряд саботує мовний закон - Смолій. Агениія інформації та аналітики "Galinfo». URL: https://galinfo.com.ua/news/uryad_sabotuie_movnyy_zakon_smoliy_ 328567.html. (Дата звернення: 25.03.2020)

${ }^{8}$ Уряд створив Національну комісію зі стандартів державної мови. Урядовий портал. URL: https://www.kmu.gov.ua/news/uryad-stvoriv-nacionalnu-komisiyu-zistandartiv-derzhavnoyi-movi. (Дата звернення: 25.04.2020)

9 Монахова прагне бути адвокатом «мовного» закону. Укрінформ. URL: https://www.ukrinform.ua/rubric-society/2839276-monahova-pragne-buti-advokatommovnogo-zakonu.html. (Дата публікації: 16.12.2019. Дата звернення: 25.04.2020) 
змогу служити в українській армії, здобувати вищу освіту в Україні, вступити на держслужбу тощо. Омбудсменка наголосила, що кримінальної відповідальності за порушення мовного закону не передбачено, проте застосовуватиметься адміністративна - різного рівня штрафи. При цьому особистим вибором людини $є$ те, якою мовою вона спілкується в побуті, за що не може бути покарання.

Тим часом Венеціанська комісія ухвалила рекомендації щодо закону України «Про забезпечення функціонування української мови як державної». Свропейська інституція визнає і повністю підтримує той факт, що українська мова, як державна, повинна мати особливий статус і захист. У Раді Свропи добре розуміють, що впродовж існування СРСР місце і роль російської мови на території України була суттєво вищою, отже, тепер державна мова потребує додаткової підтримки. Однак критичних зауважень куди більше. Більшість їх стосується захисту російської мови, яка дістає в мовному законі найменше прав, отже, виникає потреба балансу. Хоча разом із тим венеціанка зауважує: зменшення прав російської мови порівняно з мовами інших меншин у деяких моментах може мати об'єктивне та розумне обтрунтування. Окреме занепокоєння комісії викликало регулювання туристичної галузі, де, на думку ВК, українська мова запроваджується непродумано. Також зауважується на розмитості підстав до каральних заходів за порушення закону, значні обмеження мови мас-медіа, зокрема приватних, тощо ${ }^{10}$.

Уповноважена із захисту державної мови Тетяна Монахова прокоментувала доповідь Венеціанки. Основний меседж омбудсменки: Україна, будучи правовою державою, зверне увагу на рекомендації щодо мовного закону, зокрема й щодо дотримання прав нацменшин, $\mathrm{i}$ буде до них певною мірою дослухатися в подальшій законотворчій роботі. «Готується закон про наименшини. I от там усі иі побажання будуть прийняті до розгляду. Очевидно, ще буде готуватися відповідь офіџійна. Репліки намі на изі зауваження. Тому праџюємо. Закон є. Він чинний. Ми маємо його виконувати», - сказала пані Монахова, не відкидаючи при цьому важливості висновків європейської інституції ${ }^{11}$.

Уже в дещо іншому контексті уповноважена зазначила, що стати до виконання своїх обов'язків щодо захисту державної мови зможе через півроку, а поки що працюватиме над тим, аби запустити роботу

${ }^{10}$ Сидоренко С. Мовний закон штовхають до зміни: що рекомендує Україні Венеціанська комісія. Украӥнська правда. URL: https://www.eurointegration.com.ua/ articles/2019/12/6/7103953 (Дата звернення: 25.04.2020)

${ }^{11}$ Мовний омбудсмен прокоментувала рекомендації Венеціанської комісії. Укрінформ. URL: https://www.ukrinform.ua/rubric-polytics/2834911-movnij-ombudsmenprokomentuvala-rekomendacii-venecianskoi-komisii.html (Дата звернення: 27.04.2020) 
Секретаріату $^{12}$. Останнє, проте, виявилося просто непідйомним завданням...

За три місяці, у березні 2020 р., згадуваний вже Андрій Смолій у своєму телеграм-каналі з цитуванням уповноваженої з питань мови Тетяни Монахової повідомив: «Влада саботує виконання Закону про мову. Секретаріат уповноваженої із захисту державної мови НЕ створюється. Тобто, у разі, якщо Закон про мову не вдається скасувати, то можна зробити так, щзоб він просто не виконувався. I уряд робить все, щоб Закон не пращював». За словами Андрія Смолія, «уповноважена розповідає, що «нестворення» Секретаріату може потягнути за собою скасування Закону про мову Конституиійним Судом. А иее ще одна маячня, яка покликана підсилити невиконання Закону та грає на руку проросійським силам, які прагнуть скасування Закону» ${ }^{13}$.

А 24 квітня 2020 р. перша Уповноважена із захисту державної мови написала заяву про звільнення за власним бажанням, промовисто прокоментувавши в мережі «Фейсбук» причини такого кроку: «Завжди виконувала правило Рузвельта: "Роби, шо можеш, із тим, що маєш, там, де ти є». Та треба знайти сили вчасно усвідомити, що двері, які просто намальовані на цегляній стіні, не відчиняються» ${ }^{14}$.

Докладніше про рішення піти з посади Тетяна Монахова розповіла в інтерв»ю виданню «Opinion». Виявляється, що від часу призначення мовна омбудсменка провела безліч консультацій з юристами Верховної Ради і Кабінету Міністрів, писала проєкти постанов для Кабміну про створення секретаріату, зверталася 3 листами до депутатів, доповідаючи про труднощі, просила допомоги. Марними, за ії словами, були й спроби звернутися до Офісу Президента - до глави держави вона так і не потрапила. Намагалася зареєструвати Секретаріат у ЦНАПі Печерського району, але безрезультатно, розповіла вона. «Я мала довге терпіння, поки була ілюзія, що повільно, але впевнено я йду до мети. Однак, коли все було нарешті готово, коли після стількох моїх зусиль питання про створення секретаріату нарешті було

${ }^{12}$ Мовний омбудсмен назвала своє «завдання номер один». Укрінформ. URL: https://www.ukrinform.ua/rubric-society/2834853-movnij-ombudsmen-nazvalasvoe-zavdanna-nomer-odin.html. (Дата звернення: 27.04.2020)

${ }^{13}$ Якщо не вдасться скасувати Закон про мову, то «Слуги народу» підсилять його невиконання. Патріот Донбасу. URL: https://donpatriot.news/iakshcho-nevdastsia-skasuvaty-zakon-pro-movu-to-sluhy-narodu-pidsyliat-joho-nevykonannia (Дата звернення: 29.03.2020)

${ }^{14}$ Монахова Т. [Tetiana Monakhova] [Повідомлення про рішення звільнитися 3 посади Уповноваженої із захисту державної мови]. Facebook. URL: https://www.facebook.com/permalink.php?story_fbid= $2567962936854735 \& \mathrm{id}=100009231606405$ (Дата звернення: 25.04.2020) 
винесене на голосування Кабміну, а потім раптово в день голосування викреслене із порядку денного, я остаточно переконалася, щио йдеться про відсутність політичної волі. Я зрозуміла, що всі мої дї заблоковані. Продовжувати брати на себе відповідальність за те, на що ніяк не можеш вплинути, просто безглуздо», - підсумувала безперспективність дальших потуг Тетяна Монахова ${ }^{15}$.

У березні 2019 р. щоразу частіше стала 3'являтися інформація про можливе скасування положень мовного закону. 3 трибуни Верховної Ради про це з тривогою говорить Микола Княжицький з опозиційної фракції «Європейська солідарність» ${ }^{16}$. Перед тим застерігає владу від намірів ревізувати мовний закон, акцентуючи на його виваженості та збалансованості, п'ятий президент України Петро Порошенко ${ }^{17}$. Не розуміють, для чого під час карантину треба розглядати «мовні» $\mathrm{i}$ «освітні» зміни в парламентській фракції «Голос» ${ }^{18}$.

Утім, 18 березня таки відбулося засідання Комітету гуманітарної та інформаційної політики, на якому розглядали законопроєкт народного депутата від партії «Слуга народу» Максима Бужанського № 2362 про мову й освіту, який пропонує, щоби перехід для шкіл із російською мовою навчання на нові навчальні плани, які передбачають більшу частку викладання українською, відклали до вересня 2023 р., відповідно до чинного освітнього законодавства, ці зміни мають відбутися вже у вересні цього року, а для шкіл із мовами навчання країн Європейського Союзу термін переходу - до 2023 р. Як зауважила депутатка Інна Совсун (раніше - перший заступник міністра науки i освіти України), історія із засіданням комітету гуманітарної політики, в порядку денному якого несподівано з'явився розгляд освітнього законопроєкту, виглядає дуже дивно: «Справа в тому, що я, як членкиня профільного парламентського комітету (з питань освіти, науки та інновачій), бачила багато подібних законодавчих ініціатив

15 Україна залишається без мовного омбудсмена: чому Тетяна Монахова вирішила звільнитися? OPINION UA. URL: https://opinionua.com/2020/04/24/ukra\% D1\%97na-zalishayetsya-bez-movnogo-ombudsmena-chomu-tetyana-monaxova-virishilazvilnitisya (Дата звернення: 27.04.2020)

16 До Ради готують пропозиції про скасування низки положень «мовного» закону - Княжицький. Укрінформ. URL: https://www.ukrinform.ua/rubricpolytics/2902747-do-radi-gotuut-propozicii-pro-skasuvanna-nizki-polozen-movnogozakonu-knazickij.html. (Дата звернення: 27.04.2020)

${ }^{17}$ Порошенко П. [Про застереження владі ревізувати мовний закон] Facebook. URL: https://www.facebook.com/petroporoshenko/photos/a.474415552692842/19740 70169394032. (Дата звернення: 27.04.2020)

${ }^{18} \mathrm{У}$ «Голосі» не розуміють, чому «мовні» $\mathrm{i}$ «освітні» зміни треба розглядати під час карантину Укрінформ. https://www.ukrinform.ua/rubric-polytics/2899203-u-golosine-rozumiut-comu-movni-i-osvitni-zmini-treba-rozgladati-pid-cas-karantinu.html. (Дата звернення: 20.04.2020) 
щодо мови викладання. Усі вони розглядалися саме на освітньому комітеті, щуо досить логічно, зважаючи, що всі вони стосувалися мови навчання в освітніх закладах Украӥни». Цього разу ухвалення рішення щодо законопроєкту відклали для «подальших консультацій». На думку Інни Совсун, «користуючись пандемією коронавірусу та режимом карантину, монобільшість спробувала по-тихому «пропихнути» закон, який посилюе позиції російської мови в украӥнських школах», а в «таких умовах посилювати позиції мови агресора в Україні - ие злочин» ${ }^{19}$. Народний депутат Володимир В'ятрович вбачає в цьому «розгортання проросійського реваншу режимом Зеленського»: «Цей проєкт передбачає зміни в закони про мову $i$ про освіту $i$ переносить з 2020 на 2023 рік перехід російськомовних 5-11 класів на навчання украӥнською мовою. Він кілька місяиів лежав без руху. Проти нього виступило й Міносвіти, яке готове згідно з чинним законом перевести школярів на навчання украӥнською з 1 вересня, $i$ бюджетний комітет, $i$ освітянська спільнота. І ось раптом иеей проєкт, не потрібний нікому, крім Москви і ї̈ посіпак, терміново вкидають в порядок денний комітету. Вочевидь, щзоб голосами «слуг» $і$ ОПЗЖ виконати иңю московську забаганку як на комітеті, так $i$ в сесійній залі» ${ }^{20} .30$ квітня 2020 р. законопроєкт № 23632 «Про внесення змін до деяких законодавчих актів України щодо навчання державою мовою в закладах освіти» авторства Максима Бужанського знову з'явився на порядку денному засідання Комітету 3 питань гуманітарної та інформаційної політики. I хоч більшістю голосів (13 з 16 присутніх членів Комітету) його відправили на доопрацювання ${ }^{21}$, напередодні депутат від «Європейської солідарності» Микола Княжицький закликав колег із фракції «Слуга народу» взагалі зняти документ із розгляду, мотивуючи це прихованою небезпекою антиукраїнської діяльності: «Завтра (30 квітня. - Авт.) наш комітет $з$ гуманітарної політики вкотре вирішив розглянути антиукраӥнський законопроєкт депутата Бужанського про обмеження вживання украӥнської мови в освіті. Мої колеги з фракиії «Слуга народу» кажуть, що немає підстав турбуватися, адже вони проголосують проти.

${ }^{19}$ Совсун I. Реванш на марші: як «слуги народу» захищають російську мову, прикриваючись карантином. Українська правда. URL: https://www.pravda.com.ua/ columns/2020/03/20/7244366 (Дата звернення: 10.04.2020)

20 «Слуги народу» намагаються змінити закон про мову - В'ятрович. Дивись.info. URL: https://dyvys.info/2020/03/17/slugy-narodu-namagayutsya-zminytyzakon-pro-movu-v-yatrovych. (Дата звернення: 10.04.2020)

21 Комітет гуманітарної та інформполітики відправив на доопрацювання законопроєкт Бужанського. Детектор медіа. URL: https://detector.media/ rinok/article/176806/2020-04-30-komitet-gumanitarnoi-ta-informpolitiki-vidpraviv-nadoopratsyuvannya-zakonoproekt-buzhanskogo. (Дата звернення: 10.04.2020) 
Втім, тут і хитрість. Розгляд законопроєкту навіть із негативним результатом дозволяе його виносити в зал. Зараз, ініціюючи розгляд проєкту $i$ запевняючи, що голосуватимуть проти, депутати від «Слуги народу» хочуть відкрити двері для антиукраӥнської діяльності своїх колег по фракиії. Дуже прошу всіх небайдужих до майбутнього украйнської мови громадян звернутися до моїх колег із фракиї «Слуга народу» з проханням зняти проєкт Бужанського з розгляду» ${ }^{22}$.

Цікаво, що за кілька тижнів до цього, 11 березня, на пленарному засіданні російської Ради Федерації було схвалено закон про визнання громадян Білорусії і України, які вільно володіють російською мовою, iii носіями без проходження співбесіди для отримання громадянства Р $\Phi^{23}$. А спікер Верховної Ради Дмитро Разумков припускав можливість перегляду мовного закону в парламенті й не виключив змін до нього щодо квот української мови. Про це він заявив в ефірі головного політичного ток-шоу на телеканалі «112 Україна», відповідаючи на запитання ведучого ${ }^{24}$. Щодо особистих мовних уподобань пан Разумков заявив, що виступає нині або російською, або українською мовами. Коли ще не обіймав посади спікера, спілкувався російською - це була його принципова позиція, аби довести, що російську мову в Україні ніхто не утискає, що нема потреби в тому, аби хтось приходив i захищав його права як російськомовного ${ }^{25}$.

На питанні квот для української мови, про можливість перегляду яких у законі парламентом згадував спікер, варто зупинитися докладніше. Адже державна політика щодо запровадження квот, яка реалізується з 2016 року, реально повернула українську мову в ефіри телеканалів і радіостанцій. На цьому факті ще наприкінці вересня 2019 р. акцентував член Національної ради 3 питань телебачення i радіомовлення Сергій Костинський. Посадовець наголошує, що політика державного протекціонізму дає посутні результати: створено

${ }^{22}$ Княжицький М. [Заклик до небайдужих громадян звернутися до нардепів фракції «Слуга народу» 3 проханням зняти законопроєкт Бужанського 3 розгляду комітету] Facebook. URL: https://www.facebook.com/mykolakn/posts/102189789585 19127 (Дата звернення: 30.04.2020)

${ }_{23}$ У Росії схвалили закон про визнання українців і білорусів «носіями російської мови». Інформаційне агентство «Українські Національні Новини». URL: https://www.unn.com.ua/uk/news/1857110-u-rosiyi-skhvalili-zakon-pro-viznannyaukrayintsiv-i-bilorusiv-nosiyami-rosiyskoyi-movi (Дата звернення: 21.04.2020)

${ }^{24}$ Разумков заявив, що Рада може переглянути закон про мовні квоти. Главком. URL: https://glavcom.ua/news/razumkov-zayaviv-shcho-rada-mozhe-pereglyanuti-zakonpro-movni-kvoti-664820.html. (Дата звернення: 25.04.2020)

25 Разумков анонсував зміни до мовного закону. Главком. URL: https://glavcom.ua/news/razumkov-anonsuvav-zmini-do-movnogo-zakonu-664832.html. (Дата звернення: 27.04.2020) 
масу нових пісень, передач $\mathrm{i}$ фільмів саме українською мовою. «За 3 роки украӥнська мова тотально повернулася в ефір телеканалів $i$ радіостаниій, а українська пісня отримала потужний розвиток $i$ сталу ротацію в ефірі радіомовників», - твердить Костинський, наводячи переконливу статистику ${ }^{26}$.

Він також повідомив, що в травні 2019 р. Нацрада з'ясовувала ставлення українців до змін у національному телерадіоефірі за 3 роки. За результатами цього соцдослідження, близько 80\% (!) опитаних надають перевагу українській як основній мові теле- й радіоефіру. Близько 60\% підтримують політику державного протекціонізму щодо збільшення українського та україномовного контенту в ефірі вітчизняних телеканалів та радіостанцій. Орієнтовно половина українців позитивно оцінює зміни в українській музичній індустрії внаслідок впровадження квот на українськомовну музику.

Продюсер телеканалу «М 2» Роман Муха впевнений: державний протекціонізм був єдино правильним рішенням, адже сприяв величезним змінам. Через 3 роки після запровадження квот телеканал отримує 6-7 відеокліпів кожного тижня, тоді як 3 роки тому мали тільки 1 кліп, чого було замало, аби канал вижив. Тобто виробництво відеокліпів зросло вшестеро, крім того, значно поліпшилася їхня якість. «Введення квот залучило в музичну індустрію близько 100 тисяч людей по всій краӥні аранжувальників, музикантів, звукові студї, світлове обладнання тощо. Тобто введення квот - це колосальні зміни не тільки в культурі, а $і$ в структурі зайнятості», - підкреслив продюсер ${ }^{27}$.

До слова, за шість років Нацрада обмежила мовлення 74 російських каналів $^{28}$, за період дії мовних квот оштрафувала українські радіостанції на майже 1,8 млн грн, завдяки чому впродовж 2019 р. порушень майже не фіксувалося ${ }^{29}$. Мало того, регіональні радіостанції на $17 \%$ перевиконують мовні квоти, тобто кожна друга пісня в ефірі нині звучить українською ${ }^{30}$. Утім, 5 березня Президент Володимир

${ }^{26}$ Квоти повернули українську музику на радіо і телебачення - Нацрада. Українська правда. https://www.pravda.com.ua/news/2019/09/25/7227300 (Дата звернення: 27.04.2020)

27 Там само.

28 За шість років Нацрада обмежила мовлення 74 російських каналів. Укрінформ. URL: https://www.ukrinform.ua/rubric-society/2891143-za-sist-rokiv-nacrada-obmezilamovlenna-74-rosijskih-kanaliv.html (Дата звернення: 21.04.2020)

${ }^{29}$ Мовні квоти: Нацрада оштрафувала радіостанції на майже 1,8 мільйона. Укрінформ. URL: https://www.ukrinform.ua/rubric-society/2874668-movni-kvotinacrada-ostrafuvala-radiostancii-na-majze-18-miljona.html (Дата звернення: 22.04.2020)

${ }^{30}$ Регіональні радіостанції перевиконують мовні квоти - Костинський. Укрінформ. URL: https://www.ukrinform.ua/ rubric-society/2874892-regionalniradiostancii-perevikonuut-movni-kvoti-kostinskij.html. (Дата звернення: 22.04.2020) 
Зеленський достроково звільнив членів Нацради з питань телебачення $\mathrm{i}$ радіомовлення Сергія Костинського і Уляну Фещук, які активно втілювали політику державного протекціонізму української мови в теле- і радіоефірах. Для обох таке рішення стало щонайменше неочікуваним і дивним ${ }^{31}$.

У контексті використання української мови на телебаченні не можна обійти увагою скандал довкола висловлювань про мову мелодрам і комедій головної продюсерки серіалів та фільмів каналу «1+1» Олени Єремеєвої. У публікації на сайті «Телекритика» пані повідомила, що комедії для осіннього сезону були зняті винятково українською мовою, а всі 7 мелодрам - російською. Причина, мовляв, у тому, що знайти тональність української мови, аби глядач ії сприймав, досить непросто. I мелодрами українською мовою виглядають гірше, ніж комедії. Та й артистам поки ще важко працювати українською мовою. Отже, продукти для весняного сезону зробили російською мовою, тому що українська складніша для цього жанру. Та й продаваність серіалів українською гірша, бо ринок обмежується тільки Україною ${ }^{32}$.

Такий погляд на українську як другосортну, звичайно, страшенно збурив громадськість, і хвиля гнівного невдоволення з усіх можливих комунікаційних каналів ${ }^{33}$ змусила продюсерку перепрошувати й пояснювати свої слова тим, що їх вихопили з контексту тощо, ба навіть заявити про плани телеканалу збільшити цього року кількість українськомовних продуктів удвічі ${ }^{34}$.

Утім, окрім відвертого цинізму, а можливо, й непрофесіоналізму продюсерки популярного в масової аудиторії каналу, меркантильної політики самого телевізійного мовника на шкоду національномовному інтересу, ситуація засвідчила й зростання в Україні громадянського суспільства та його щораз більший вплив на високопосадовців як державного, так і комерційного сектора. Отже, і перспективи спільно відстояти досягнення в мовній царині останніх часів у разі ймовірних

${ }^{31}$ Костинський і Фещук не розуміють, чому їх звільнили з Нацради. Укрінформ. URL: https://www.ukrinform.ua/rubric-society/2891288-kostinskij-i-fesuk-ne-rozumiutcomu-ih-zvilnili-z-nacradi.html. (Дата звернення: 28.04.2020)

${ }^{32}$ Телеканал готовит к показу драматические и комедийные сериалы и заявляет о желании развивать предпраймовый слот. Телекритика. URL: https://telekritika.ua/smeh-i-slezy-kakie-plany-1-1-po-proizvodstvu-kontenta-na-2020-god.

(Дата звернення: 27.04.2020)

33 Українська не для мелодрам? 1+1 втрапив у мовний скандал. ВВС Украӥна. URL: https://www.bbc.com/ ukrainian/51404360. (Дата звернення: 28.04.2020)

${ }^{34}$ Олена Єремєєва: «Мої слова про мовне питання були вирвані 3 контексту». Телекритика. URL: https://telekritika.ua/uk/olena-€remєєva-moï-slova-pro-movnepitannya-buli-virvani-z-kontekstu. (Дата звернення: 28.04.2020) 
загроз із боку не надто українськоцентричної i здебільшого ще малодосвідченої чинної влади виглядають не так уже й примарно.

Позитивом у мовній політиці держави згаданого періоду можна вважати намір Міністерства культури, молоді та спорту (МКМС) до 1 вересня 2020 р. запустити безплатну онлайн-платформу для вивчення української мови, озвучений на початку січня 2020 р. очільником Мінкульту Володимиром Бородянським. За його словами, навчальні курси планують розділити на окремі категорії: для тих, хто знає мову, але хоче їі поліпшити; тих, хто не володіє мовою і планує вивчення «з нуля»; для державних службовців, які хочуть удосконалити свої знання $^{35}$. Про цю ж платформу наприкінці лютого згадує i перший заступник міністра культури, молоді та спорту України Анатолій Максимчук, говорячи про запуск найближчим часом тендеру на іiі створення. Також він анонсує деякі кроки на підтримку державної та інших мов в Україні, зокрема кримськотатарської, покладаючись на інституції, які є у сфері управління міністерства, згадує про розвиток жестової мови, а також про пошук рішення, як забезпечити вивчення державної мови в офлайні ${ }^{36}$. Утім, чи здійснюватимуться ці плани після березневої відставки уряду, в тому числі й зміни керівництва Мінкульту, невідомо.

У мовнополітичному ракурсі варто згадати круглий стіл до Дня рідної мови, що відбувся у лютому 2020 р. в Києві, роботу якого модерував голова Комітету з Національної премії України імені Тараса Шевченка, головний редактор Суспільного телебачення Юрій Макаров. Зокрема, тут порушили питання і про методику викладання української мови як державної. Голова Національної комісії зі стандартів державної мови Орися Демська висловила думку, що напрацювання методики викладання української мови - це не завдання міністерств, а завдання інтелектуалів: «I изі методики мають входити в ширше коло питань для чого дитині, для чого людині потрібна мова? Для того, щуоб комунікувати, щуоб формулювати свої думки. Для того врешті, щуоб створити вербальний портрет нашого майбутнього». На думку мовознавиці, тільки-но ми вийдемо в площину «мова для мислення», «мова як інструмент формування світу, формування себе» i, відповідно, викладання мови для того, щоб дитина мала інструмент

${ }^{35}$ Вивчення української «з нуля»: МКМС запустить безкоштовну онлайнплатформу. Укрінформ. URL: https://www.ukrinform.ua/rubric-society/2853157vivcenna-ukrainskoi-z-nula-mkms-zapustit-bezkostovnu-onlajnplatformu.html. (Дата звернення: 27.04.2020)

${ }_{36}$ MКМС запустить проєкти на підтримку української та мов нацменшин. Укрінформ. URL: https://www.ukrinform.ua/rubric-society/2881578-mkms-zapustitproekti-na-pidtrimku-ukrainskoi-ta-mov-nacmensin.html (Дата звернення: 27.04.2020) 
бачити себе, представити себе світові, бути частиною світу - ми тут же забудемо про підмети і присудки: «Вони залишаться як уявлення про систему, про структуру мови. Але граматичний підхід до вивчення державної мови, будь-якої мови безнадійно застарів. Він формує патерналістичне суспільство» ${ }^{37}$.

\section{2. Новочасні обриси угорського, румунського та «русинського» питання}

На окрему увагу заслуговує дальше простеження динаміки штучно розпалюваної і підтримуваної в заявах політиків та публікаціях медіа псевдоконфронтації на міжетнічному грунті, що спостерігається, передусім, на Закарпатті і виявляється, зокрема, в кількарічному українсько-угорському (меншою мірою - українсько-румунському) освітньо-мовному протистоянні чи в роздмухуванні русинської теми. Наскільки трансформувалися i чи змінилися взагалі тенденції попередніх років із приходом нової влади?

Власне, найзагальніші висновки щодо першого, очевидно, можна грунтувати на висловлюваннях віцепрем'єр-міністра 3 питань європейської та євроатлантичної інтеграції, а нині вже міністра закордонних справ України Дмитра Кулеби, що прозвучали в інтерв'ю виданню «Сегодня» у жовтні $2019 \mathrm{p}^{38}$.

Український урядовець заявив, що ситуація, коли Угорщина домінує в угорській громаді Закарпаття, коли місцеві угорці не володіють українською і навіть російською мовою, а знають лише угорську, є неприйнятною. Він наголосив при цьому, що Україна хоче, аби ці люди шанували свою культуру, пам'ятали, що вони є угорцями, вільно володіли рідною мовою і могли вільно подорожувати до Угорщини. Водночас наша держава прагне, щоб вони завжди пам'ятали, що є громадянами України, і це теж їхня земля, що це їхня країна, й аби вони розмовляли мовою цієї країни, розуміли ії історію та історичне значення. Тобто меседж політика однозначний: у відносинах 3 Угорщиною на Закарпатті вже не буде так, як до ухвалення Україною нового закону про освіту. "Ситуації, коли лише угорська частина історії праџювала, а Україна, по суті, була відсутня, вже не буде. Коли наші угорські партнери сприймуть иеей факт, тоді вони будуть здатні

${ }^{37}$ Україна потребує нової методики викладання державної мови - Макаров. Укрінформ. URL: https://www.ukrinform.ua/rubric-society/2881726-ukraina-potrebuenovoi-metodiki-vikladanna-derzavnoi-movi-makarov.html. (Дата звернення: 27.04.2020)

${ }^{38}$ Інтерв’ю 3 Дмитром Кулебою: «Україна вже подала заявку на отримання ПДЧ». Сегодня. URL: https://www.segodnya.ua/ua/ukraine/intervyu-s-dmitriemkuleboy-ukraina-uzhe-podala-zayavku-na-poluchenie-pdch-1350312.html. (Дата звернення 26.04.2020) 
знайти з нами збалансоване рішення, до якого ми готові, коли інтереси $i$ Угорщини, $і$ України будуть враховані», - підсумував Д. Кулеба міждержавну ситуацію і прийнятні шляхи їі врегулювання ${ }^{39}$.

Нині ж Угорщина продовжує пред’являти претензії до України через два закони, ухвалені у 2017 р. (Закон «Про освіту») і 2019 р. (Закон «Про функціонування української мови як державної»), як такі, що нібито порушують право на використання рідної мови національними меншинами. Наприкінці жовтня 2019 р. Угорщина наклала вето на спільну заяву послів НАТО стосовно України, і в листопаді голова комітету парламенту Угорщини з питань національної єдності Янош Бенцик заявив, що Угорщина і надалі послідовно блокуватиме зближення України 3 Північноатлантичним альянсом та $\mathrm{CC}^{40}$.

Тим часом заступник голови Закарпатської облради Йосип Борто в інтерв’ю угорськомовній газеті Закарпаття «Kiszo» повідомляє, що місцева угорська громада звернулася до центральної влади України 3 проханням сформувати в рамках децентралізації об'єднану територіальну громаду з центром у Берегові так, щоб туди увійшли населені пункти переважно 3 населенням угорського походження ${ }^{41}$. Зрозуміло, що такі дії, як правило, інспіруються з-за кордону.

18 листопада МЗС України оприлюднило офіційну заяву щодо заключного Комюніке XVIII засідання Угорської постійної ради, висловлюючи протест у зв'язку із закликами до втручання у внутрішні справи суверенних держав: «Засуджуючи заклики до автономіі угорських спільнот Карпатського регіону, наголошуємо на тому, що національні меншини в Украӥні користуються конституційним правом на культурну автономію $i$ що підтримка інших форм автономії суперечать украӥнському законодавству $i \in$ посяганням на територіальну иілісність.

У контексті наміру угорської сторони реалізовувати програми $з$ надання допомоги закордонним угориям зазначаємо, щчо процедура надання такої допомоги має узгоджуватися з краӥнами проживання угорських громад та надаватися у прозорий та недискримінаційний спосіб.

${ }^{39}$ Інтерв'ю $з$ Дмитром Кулебою.

40 Посол Угорщини обіцяє: Будапешт і надалі блокуватиме роботу форуму Україна-НАTO. Главком. URL: https://glavcom.ua/country/society/posol-ugorshchiniobicyaje-budapesht-i-nadali-blokuvatime-robotu-forumu-ukrajina-nato-643159.html.

(Дата звернення 26.03.2020)

41 Закарпатські угорці прохатимуть Київ створити «угорський» район з центром у Берегові. Mukachevo.net. URL: http://www.mukachevo.net/ua/news/view/627578 (Дата звернення 27.03.2020) 
Також нагадуємо, що Конституиійний Суд Украйни визнав Закон Украйни «Про освіту» таким, що відповідає Конституиії, i що шість із семи висловлених Венеціанською Комісією рекомендацій для імплементації иъього закону Украӥною вже виконані. Після виконання останньої, сьомої, рекомендацї ми очікуємо на розблокування Будапештом діалогу Украӥни з НАТО.

Важливим для Украӥни є елементи Комюніке з висловленням готовності до нормалізації відносин Украйни та Угорщини.

Закликаємо угорську сторону припинити необтрунтовані звинувачення на адресу України в порушеннях прав угорської меншини та продовжити праџювати в напрямі відновлення атмосфери довіри $i$ добросусідського співробітництва, що відповідає також інтересам національних меншин, щзо проживають у наших державах ${ }^{42}$.

Наприкінці листопада 2019 р. посол Угорщини Іштван Ійдярто (родом із Берегова. - авт.) запевнив, що в Угорщини не може бути територіальних претензій до України і вона не блокує процесу інтеграції України в НАТО: «Ми блокуємо лише один форум, це політичний рівень - Рада Украӥна-НАТО. I будемо блокувати далі. Чому ми блокуємо спільні декларації на цььому політичному рівні? Тому що вважаємо НАТО не тільки військовою організацією. Якщо ти хочеш стати членом НАТО, у тебе повинні бути зобов'язання дотримуватися прав людини. На наш погляд, прийнятий закон про освіту суперечить ичим принципам. Хочу підкреслити, щя все це аж ніяк не заважає інтеграџії, військовій, адміністративній Украӥни з $H A T O \gg^{43}$.

Незважаючи на постійні твердження офіційного Будапешта та його представників в Україні (КМКС-ТУКЗ, ДСУУ) щодо утисків угорськомовного населення регіону, особливо щодо права на освіту, Україна, зі свого боку, продовжує робити кроки щодо забезпечення основних прав і свобод національних меншин, які проживають в Україні. Зокрема, ухваленням Закону «Про повну загальну середню освіту» 16.01 .2020 р. виконано ключові рекомендації Венеціанської комісії щодо мови освіти, які стосувалися навчання мовами Свросоюзу, а отже, і угорською.

42 Рішучий крок: Офіційний протест МЗС України проти угорської автономії на Закарпатті. Mukachevo.net. URL: http://www.mukachevo.net/ua/news/view/658598 (Дата звернення: 12.04.2020)

43 Глуховський М., Груздєв С. Посол Угорщини Іштван Ійдярто: Ми будемо блокувати Раду Україна-НАTO і далі. Главком. URL: https:/glavcom.ua/interviews/ posol-ugorshchini-v-ukrajini-ishtvan-iydyarto-mi-blokujemo-i-budemo-blokuvati-daliradu-ukrajina-nato-642853.html (Дата звернення: 12.04.2020) 
Оновлення мовних норм у цьому документі не припинило, однак, конфліктної ситуації з Угорщиною: реакція на новий закон виявилася негативною, а виконання вимог незалежного міжнародного арбітра непоміченими. 3 угорського боку далі лунають заяви, мовляв, новий освітній закон України «ліквідовуе угорські національні школи», відкриває шлях до асиміляції угорців та втрати ними ідентичності. Експерти висловлюють думку, що «мова освіти для угорської громади - ие інструмент збереження власної ідентичності, а для офіиійних структур Угорщини - можливість втручатись у внутрішні справи України» ${ }^{44}$.

7 лютого 2020 р. міністр закордонних справ Угорщини Петер Сійярто передав міністерці освіти і науки України Ганні Новосад пропозиції щодо навчання угорців на Закарпатті української мови. Про це він повідомив на прес-конференції з віцепрем'єр-міністром із питань європейської та євроатлантичної інтеграції України Дмитром Кулебою, зауваживши: «Ми розуміємо, що Україна хоче, аби їі громадяни на всій iii території володіли українською мовою й розмовляли нею. А ми бажаємо, щоби угорці, які проживають на Закарпатті, мали змогу зберегти свою рідну мову» ${ }^{4}$.

Нині вже ексміністриня освіти і науки Ганна Новосад заявила тоді про припинення політичних дискусій 3 Угорщиною щодо мовного питання в школах із мовою навчання національних меншин: «Ми закриваємо політичні дискусї щодо мовного питання для шкіл $з$ мовою навчання наименшин $і$ зосереджуємося на роботі з учителями та методистами. Для нас ие дуже важливо, адже основна иіль - щоб усі українські діти, незалежно від їхнього етнічного походження, на високому рівні володіли державною мовою». Ганна Новосад зауважила, що Україна поважає конституційне право кожної дитини вивчати рідну мову й навчатися нею, і дискусія має бути сконцентрована навколо підвищення якості навчання. Що ж до пропозиції угорської сторони прирівняти угорську мову до мови корінного народу, то міністриня слушно відповіла, що це політичне питання: «Корінні народи у нас чітко визначені в законодавстві. Корінними народами наразі розглядаються ті, що не мають іншої держави, крім України, яка

${ }^{44}$ Нові мовні норми: чергові претензії з боку Угорщини. Madyar.info - Новини Закарпаття. URL: http://www.madyar.info/27/01/2020/novi-movni-normy-chergovipretenziyi-z-boku-ugorshhyny (Дата звернення: 7.04.2020)

45 Угорщина передала МОН України свої пропозиції щодо навчання угорців на Закарпатті української мови. Закарпаття онлайн. URL: https://zakarpattya.net.ua/ News/199343-Uhorshchyna-peredala-MON-Ukrainy-svoi-propozytsii-shchodonavchannia-uhortsiv-na-Zakarpatti-ukrainskoi-movy (Дата звернення: 5.04.2020) 
відстоює розвиток їхньої культурної та мовної спадщини. Угорська мова під ией принцип не підпадає» ${ }^{46}$.

У лютому 2020 р. на одному з інтернет-ресурсів з'явилися сканкопії листів, датованих 16.02 .2020 р., від представників румунської спільноти Закарпаття: звернення підписали голова обласної спілки румунів Закарпаття «Дачія» Іван Ботош, керівник соціальнокультурного товариства румунів Закарпаття ім. Іона Міхалі Де Апша Йовдій Василь та очільниця соціально-культурного товариства румунів Закарпаття ім. Кожбука Опріш Руксандра. У ньому вкотре йдеться про неприпустимість запровадження законів України «Про повну загальну середню освіту», «Про освіту» та «Про забезпечення функціонування української мови як державної», оскільки вони заважають нормальному життю румунів Закарпаття. Інтернет-видання припускає, що це зроблено на прохання секретаря громадської організації «Міжрегіональне об'єднання румунська спільнота України» Ауріки Божеску, яка 12 лютого 2020 р. разом із головою ТУКЗ-КМКС Василем Брензовичем, президентом Міжрегіонального об'єднання «Румунська спільнота України» Іваном Попеску та президентом Асоціації болгар України Антоном Кіссе мали зустріч з Свропейським комісаром із питань європейської політики сусідства та перемовин із розширення Олівером Варгеї, який того ж дня мав зустріч із тодішнім міністром закордонних справ України Вадимом Пристайком. Цілком імовірно, на думку видання, що це чергова ініціатива Василя Брензовича, який знову «звинувачує українську владу у надуманому переслідуванні представників національних меншини, порушенні їх прав і свобод» ${ }^{47}$.

Цікавою з погляду порівняння українського та угорського мовного законодавства є стаття, опублікована на закарпатському сайті «Varosh» наприкінці 2019 р., в якому українсько-угорська перекладачка Інга Деяк, редакторка часопису українців Угорщини «Український вісник», авторка українськомовного блогу про угорську столицю «Будапешт: канікули для душі», звертається до змісту закону «Про угорську мову як державну» (його текст $\epsilon$ на угорському юридичному порталі net.jogtar.hu у розділі «Тисячолітні закони»), ухваленому в Угорщині 175 років тому в непростих умовах, коли угорська мова була практично витіснена з різних сфер ужитку латиною та німецькою. Інга Деяк звертає увагу на те, що документ «дуже схожий на той, що

${ }^{46}$ Новосад за результатами зустрічі з Сіярто: Ми закриваємо політичні дискусії щодо мовного питання в школах із мовою нацменшин. Iнтерфакс-Украӥна. URL: https://ua.interfax.com.ua/news/political/639986.html. (Дата звернення: 8.04.2020)

47 Чергові спекуляції на тему утисків національних меншин регіону. Анонс Закарпаття. URL: http://anons-zak.com.ua/politika/28852-chergov-spekulyacyi-natemu-utiskv-naconalnih-menshin-regonu.html. (Дата звернення: 05.04.2020) 
недавно був ухвалений в Україні і викликав стільки непорозумінь $i$ претензій, адже згідно з ним: усі закони в Угорщині мають створюватися $і$ бути написані угорською мовою; мова королівських документів, поданих у парламент, має бути угорська; мова судів, усі судові укази, постанови та позови мають бути угорською; мова парламенту має бути угорська; на території Угорщини абсолютно всі установи мають вести діловодство угорською мовою; навчання у всіх школах має відбуватися угорською мовою». При цьому авторка резонно зауважує, що «якби не ией закон, сьогодні угориі навряд чи говорили б угорською, та й чи збереглася би така краӥна в сериі

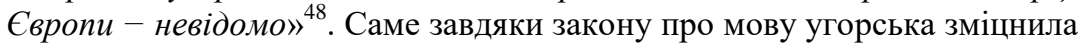
свої позиції настільки, що, попри ухвалений 2011 р. закон про національності, який дозволяе національним меншинам Угорщини здобувати освіту своєю рідною мовою, ті представники національних меншин, які хочуть в Угорщині залишитися назавжди, угорську вивчають обов'язково. Зміст статті $є$ гарною ілюстрацією того, що доля угорської мови дуже подібна до української. Можливо, саме через це, припускає Інга Деяк, угорцям і українцям так складно у мовному конфлікті порозумітися: питання мови для обох націй $€$ однаково принциповим і однаково важливим - державним.

Крім т. зв. угорського питання, на Закарпатті час від часу порушується й «русинське». Так, із медіа стало відомо, що 3 вересня 2019 р. президент Чехії Мілош Земан у резиденції на празькому Граді прийняв делегацію «Світової ради підкарпатських русинів» 3 нагоди 100-річчя початку перебування Підкарпатської Русі (по суті, нинішнього Закарпаття) у складі Чехословаччини. За повідомленнями чеських ЗМІ, делегація, до складу якої ввійшли Василь Джуган - голова Світової ради підкарпатських русинів у Чехії, його заступник Михайло Тяско, а також Дмитро Сидор, православний священник УПЦ (МП), засуджений у 2012 р. в Україні (на три роки умовно) за сепаратизм, - обговорила із Земаном питання «більшої автономії Закарпатської області в Україні». Заступник голови Світової ради підкарпатських русинів Михайло Тяско наголосив, що «украӥнська влада дотепер не визнає, не поважає нашу мову $і$ нашу культуру»; зі свого боку, чеський президент «пообіияв русинам, що про ӥхні проблеми говоритиме з украӥнським президентом Володимиром Зеленським». У публікації на сайті «Радіо Свобода» підкреслено, що «Президент Чехії Мілош Земан не вперше зустрічається з лідерами однієї з організацій чеських русинів і має з ними тісні контакти. У 2017 рочі,

\footnotetext{
${ }^{48}$ Мова єднає: Інга Деяк про схожість долі української та угорської мов. Varosh. URL: https://varosh.com.ua/dumky/inga-deyak-poyasnyla-chym-podibna-dolya-ukrayinskoyita-ugorskoyi-mov. (Дата звернення: 05.04.2020)
} 
зокрема, Василь Джуган і Михайло Тяско супроводжували чеського лідера nід час його поӥздки до Росії. А після зустрічі з Земаном 6 вересня иього року Михайло Тяско оприлюднив нове фото у соимережсах - знову на шилях до Росї̈ у складі делегаиії чеських підприємиів» ${ }^{49}$.

Попри те, закарпатське обласне телебачення тривалий час перебуває у стані реформування, його русинська редакція продовжує працювати, a теперішній продюсер філії ПАТ «Національна суспільна телерадіокомпанія України» «Закарпатська регіональна дирекція» Свген Тичина в лютневому інтерв'ю за 2020 р. журналістці Наталії Толочко на запитання «Як ставиться Київ до програми для русинів, адже вони не с національною меншиною? Уому ця програма досі виходить?» відповів: «На жаль, за русинами тягнеться негативний шлейф сепаратистів, які мріють про територіальне розділення. Багато в чому вони самі посприяли иьому. Але $\epsilon$ люди, які ідентифікують себе русинами, й ми це пояснюємо в Києві. Наводимо приклад сусідніх краӥн, уяких вони визнані меншиною йде для них виходять телепрограми. А в Україні ми кажемо, щчо їх немає: законодавчо вони не визнані корінним народом, хоча вони є вихідиями із Закарпаття. ПАТ «НСТУ» мусить забезпечити культурологічні потреби иих людей. Держава має вирішити, як їй поводитися з русинами. Поки щзо держава робить вигляд, щзо їх не існує» ${ }^{50}$.

На такий коментар доволі однозначно відреагував інфоресурс «Закарпаття онлайн»: «В інтерв»ю журналістиі Наталії Толочко молодий чоловік, розповідаючи про зміни, які відбудуться на телеканалі «UA: Закарпаття» у 2020 роиі, у відповідь на чіткі запитання автора без жодного сумніву вивів русинів на рівень окремого народу з окремою, «не украӥнською» мовою. За яким однозначно проглядається окрема державність, але «негативний шлейф сепаратистів, які мріють про територіальне розділення» $Є$. Тичина воліє не помічати. Орієнтиром для нього $\epsilon$ досвід сусідніх країн, які толерують $i$ пропагують русинство як, у випадку Угорщиини, зручний політичний важіль для втілення своїх ревізіоністських інтересів, а у випадку Словаччини - як спосіб розділення монолітної $i$ виливової украӥнської меншини на

${ }^{49}$ Пеленська О. Лідери русинів обговорили з президентом Чехії «більшу автономію» українського Закарпаття. Padio Свобода. URL: https://www.radiosvoboda.org/a/zeman-irusyny/30157383.html. (Дата звернення: 5.04.2020)

${ }_{50}$ Посилення інформаційної години аналітикою, оновлені програми для нацменшин, співпраця із продакшенами: яким буде «UA: Закарпаття» у 2020 році. STV: Cycniльне. Detector_Media. URL: https://stv.detector.media/reformuvannya/regional_movnyky/ posilennya_informatsiynoi_godini_analitikoyu_onovleni_programi_dlya_natsmenshin_spivprat sya_iz prodakshenami_yakim_bude_ua_zakarpattya_u_2020_rotsi. (Дата звернення: $5.0 \overline{4} .2020)$ 
взаємопоборюючі та маніпульовані тамтешньою владою сегменти (класичне divide et iтреra - розділяй і володарюй).

Попри те, щуо в Україні русинство активно використовується державами, зачікавленими в розчленуванні України, зокрема, фактично, було створене і профінансоване на Закарпатті спецслужбами Російської Федерації, яка спериу в аналогічний «гібридний» спосіб «освоїла», а згодом прямо окупувала украӥнські Крим і Донбас, С. Тичина не бачить в цььому жодної проблеми. Більше того, вважає, щчо «етнічне Закарпаття, діалект, традицію, культуру, мову» закарпатців можна пропагувати виключно під цимм сумнівної якості політичним брендом. I переконаний, щуо якщо він «працюватиме» на розвиток русинства, то плоди изієі праџуі не будуть використані Росією. А тому, мабуть, Є. Тичині перед тим, як братися за те, в чому, за його власним зізнанням, він «не є фахівцем», варто поспілкуватися з тими, хто такими фахівцями $\epsilon . A$ заодно побесідувати з людьми в украӥнській спецслужбі, які зможуть розповісти йому цуккаві факти з історії виникнення $і$ деякі сучасні реалії изього питання на Закарпатті» ${ }^{51}$.

Закарпатський поет Андрій Любка 3 цього приводу на власній сторінці у ФБ написав: «Обережно, не впадіть зі стільия: за наші з вами гроші суспільний мовник буде й надалі випускати програми «русинською» мовою, ще й титрувати $\ddot{~}$ украӥнську мову (діалект) украйнською мовою! Фактично мова про те, щуо держава за бюджетні кошти фінансує створення квазісепаратистського продукту $і$ камуфлює изе під виглядом «національної мениини». Я сподівався, що цей проект, започаткований у свій час балогівською командою і пізніше підтриманий регіоналами, нарешті в рамках реструктуризачиї ліквідують. Але ніт!

Науковцями давно $і$ мільйон разів доведено, щзо не існує ніякої русинської мови й народу, але продюсер UA: Закарпаття, який узагалі не орієнтується в цій темі, вирішив, щуо так $і$ має бути, тому в Києві переконує керівництво, щуо ц̧ю програму треба личити в сітці. Цікаво, це так виглядає державний інтерес $і$ изільове використання коштів перекладати украӥнську украӥнською?!

Пан Тичина, з яким особисто я пов'язував надї на оновлення й осучаснення регіонального мовлення, свою позицію аргументує тим, щзо в сусідніх країнах русини визнані $і$ є програми "русинською мовою». Так правильно, бо сусідні краӥни вже не одне десятиліття фінансують

51 Продюсер «Суспільного» на Закарпатті збирається пропагувати «русинство» всупереч фахівцям і Україні. Закарпаття онлайн. URL: https://zakarpattya.net.ua/ News/199509-Prodiuser-Suspilnoho-na-Zakarpatti-zbyraietsia-propahuvaty-rusynstvovsuperech-fakhivtsiam-i-Ukraini. (Дата звернення: 5.04.2020) 
ідею, що закарпатиі - це не украӥнці, бо ия ідея дозволяє їм будувати плани на окупацію Закарпаття. Яким невігласом треба бути, щоб цьього простого факту не розуміти?!

Та найгірше, що все че відбувається паралельно з масовим скороченням праиівників і ефірного часу. Виходить, що першокласну програму Студія «Ранок на Тисі» з чудовим колективом треба закрити, бо нема грошей, а в цей же час залишити безглузду програму, в якій навіть закарпатський діалект спотворюється покручами й русизмами?!»" ${ }^{52}$.

\section{ВИСНОВКИ}

Підсумовуючи викладене, можемо констатувати, що мовна політика України за нового президента, парламенту й уже двох урядів (впродовж вересня 2019 р. - початку травня 2020 р.) кардинальних змін не зазнала i радше продовжує рух (хоч, можливо, й за інерцією) у фарватері, прокладеному попередньою владною командою. Деякі означені гальмівні процеси в питанні реалізації вимог ухваленого мовного закону можуть бути пояснені як небажанням їх виконувати і спробами змінити або частково скасувати, так і елементарною недосвідченістю, подекуди й некваліфікованістю більшості державного апарату всіх рівнів, а також звичною в усі періоди бюрократичною системою.

У питаннях взаємин між Україною та сусідніми державами в контексті дотримання освітніх і мовних прав етноспільнот також посутніх відхилень у бік поліпшення чи погіршення курсу нині не спостережено. Представники чинної української влади готові шукати порозуміння, встановлювати баланс у різнопланових міжнаціональних зносинах, але не за рахунок умотивованих інтересів України та ії державної мови.

Сталою залишається й ситуація з русинською темою, яка вряди-годи мусується, але не виходить за звичні рамки.

\section{АНОТАЦІЯ}

Публікація присвячена відстеженню й аналізу мовнополітичних подій в Україні за період від вересня 2019 р. до квітня 2020 р. на основі їх відображення в інтернет-медіа України, у тому числі й регіональних. Звернено увагу, що серед низки наведених фактів у контексті нової суспільно-політичної парадигми окремі $є$ тривожними сигналами. До них зараховано, передусім, той, що перша уповноважена із захисту державної мови написала заяву про звільнення за власним бажанням 3 акцентуванням на відсутності політичної волі в Україні приймати державницькі рішення в аспекті напрацювання реальних механізмів

52 Любка A. [Про програми «русинською» мовою на закарпатському суспільному телебаченні] Facebook. URL: https://www.facebook.com/andriy.lyubka/ posts/2691178374250521. (Дата звернення: 10.04.2020) 
упровадження мовного закону в життя. Невмотивованим виглядає й факт обговорення законопроєкту народного депутата від партії «Слуга народу» Максима Бужанського № 2362 про мову й освіту під час засідання Комітету з питань гуманітарної та інформаційної політики, та ще й у період карантину, в той час, як освітні питання зазвичай розглядаються профільним парламентським комітетом (із питань освіти, науки та інновацій) тощо. I хоч загалом мовна політика України за вказаний період кардинальних змін не зазнала, це може сприйматися і як рух за інерцією. Значна увага приділена також темі кількарічного вже українсько-угорського (меншою мірою - українсько-румунського) освітньо-мовного протистояння. Посутніх відхилень у бік поліпшення чи погіршення курсу тут нині не спостережено. Щодо теми політичного русинства, то вона порушується, але за звичні рамки не виходить.

\section{ЛІТЕРАТУРА}

1. Вивчення української «з нуля»: МКМС запустить безкоштовну онлайн-платформу. Укрінформ. URL: https://www.ukrinform.ua/rubricsociety/2853157-vivcenna-ukrainskoi-z-nula-mkms-zapustit-bezkostovnuonlajnplatformu.html. (Дата звернення: 27.04.2020)

2. Відбулася перша сесія Верховної Ради України IX скликання (відео). Верховна Рада України: офіційний вебпортал. URL: https://www.rada.gov.ua/news/Novyny/179613.html. (Дата звернення: 20.04.2020)

3. Глуховський М., Груздєв С. Посол Угорщини Іштван Ійдярто: Ми будемо блокувати Раду Україна-HATO i далі. Главком. URL: https://glavcom.ua/interviews/posol-ugorshchini-v-ukrajini-ishtvan-iydyartomi-blokujemo-i-budemo-blokuvati-dali-radu-ukrajina-nato-642853.html. (Дата звернення: 12.04.2020)

4. До Ради готують пропозиції про скасування низки положень «мовного» закону - Княжицький. Укрінформ. URL: https://www.ukrinform.ua/rubric-polytics/2902747-do-radi-gotuutpropozicii-pro-skasuvanna-nizki-polozen-movnogo-zakonu-knazickij.html (Дата звернення: 27.04.2020)

5. За шість років Нацрада обмежила мовлення 74 російських каналів. Укрінформ. URL: https://www.ukrinform.ua/rubric-society/ 2891143-za-sist-rokiv-nacrada-obmezila-movlenna-74-rosijskih-kanaliv.html. (Дата звернення: 21.04.2020)

6. Закарпатські угорці прохатимуть Київ створити «угорський» район 3 центром у Берегові. Mukachevo.net. URL: http://www.mukachevo.net/ua/news/view/627578. (Дата звернення 27.03.2020)

7. Інтерв'ю з Дмитром Кулебою: «Україна вже подала заявку на отримання ПДЧ». Сегодня. URL: https://www.segodnya.ua/ua/ 
ukraine/intervyu-s-dmitriem-kuleboy-ukraina-uzhe-podala-zayavku-napoluchenie-pdch-1350312.html. (Дата звернення 26.04.2020)

8. Квоти повернули українську музику на радіо і телебачення Нацрада. Українська правда. https://www.pravda.com.ua/news/ 2019/09/25/7227300. (Дата звернення: 27.04.2020)

9. Княжицький М. Заклик до небайдужих громадян звернутися до нардепів фракції «Слуга народу» 3 проханням зняти законопроєкт Бужанського 3 розгляду комітету. Facebook. URL: https://www.facebook.com/mykolakn/posts/10218978958519127 (Дата звернення: 30.04.2020)

10. Комітет гуманітарної та інформполітики відправив на доопрацювання законопроєкт Бужанського. Детектор медіa. URL: https://detector.media/rinok/article/176806/2020-04-30-komitet-gumanitarnoita-informpolitiki-vidpraviv-na-doopratsyuvannya-zakonoproekt-buzhanskogo. (Дата звернення: 10.04.2020)

11. Костинський i Фещук не розуміють, чому їх звільнили 3 Нацради. Укрінформ. URL: https://www.ukrinform.ua/rubricsociety/2891288-kostinskij-i-fesuk-ne-rozumiut-comu-ih-zvilnili-znacradi.html. (Дата звернення: 28.04.2020)

12. Любка А. Про програми «русинською» мовою на закарпатському суспільному телебаченні. Facebook. URL: https://www.facebook.com/ andriy.lyubka/posts/2691178374250521. (Дата звернення: 10.04.2020)

13. МКМС запустить проєкти на підтримку української та мов нацменшин. Укрінформ. URL: https://www.ukrinform.ua/rubricsociety/2881578-mkms-zapustit-proekti-na-pidtrimku-ukrainskoi-ta-movnacmensin.html. (Дата звернення: 27.04.2020)

14. Мова єднає: Інга Деяк про схожість долі української та угорської мов. Varosh. URL: https://varosh.com.ua/dumky/inga-deyak-poyasnylachym-podibna-dolya-ukrayinskoyi-ta-ugorskoyi-mov. (Дата звернення: 5.04.2020)

15. Мовний омбудсмен назвала своє «завдання номер один». Укрінформ. $\quad$ URL: https://www.ukrinform.ua/rubric-society/2834853movnij-ombudsmen-nazvala-svoe-zavdanna-nomer-odin.html. (Дата звернення: 27.04.2020)

16. Мовний омбудсмен прокоментувала рекомендації Венеціанської комісії. Укрінформ. URL: https://www.ukrinform.ua/rubric-polytics/ 2834911-movnij-ombudsmen-prokomentuvala-rekomendacii-venecianskoikomisii.html. (Дата звернення: 27.04.2020)

17. Мовні квоти: Нацрада оштрафувала радіостанції на майже 1,8 мільйона. Укрінформ. URL: https://www.ukrinform.ua/rubricsociety/2874668-movni-kvoti-nacrada-ostrafuvala-radiostancii-na-majze-18miljona.html. (Дата звернення: 22.04.2020) 
18. Монахова прагне бути адвокатом «мовного» закону. Укрінформ. URL: https://www.ukrinform.ua/rubric-society/2839276-monahova-pragnebuti-advokatom-movnogo-zakonu.html. (Дата звернення: 25.04.2020)

19. Монахова Т. [Tetiana Monakhova] Повідомлення про рішення звільнитися 3 посади уповноваженої із захисту державної мови. Facebook. URL: https://www.facebook.com/permalink.php?story_fbid= 2567962936854735\&id=100009231606405 (Дата звернення: 25.04.2020)

20. Нові мовні норми: чергові претензії 3 боку Угорщини. Madyar.info - Новини Закарпаття. URL: http://www.madyar.info/27/ 01/2020/novi-movni-normy-chergovi-pretenziyi-z-boku-ugorshhyny (Дата звернення: 7.04.2020)

21. Новосад за результатами зустрічі з Сіярто: Ми закриваємо політичні дискусії щодо мовного питання в школах із мовою нацменшин. Інтердакс-Україна. URL: https://ua.interfax.com.ua/news/ political/639986.html. (Дата звернення: 8.04.2020)

22. Сремєєва О. «Мої слова про мовне питання були вирвані 3 контексту». Телекритика. URL: https://telekritika.ua/uk/olena-єremєєvamoï-slova-pro-movne-pitannya-buli-virvani-z-kontekstu. (Дата звернення: 28.04.2020)

23. Пеленська О. Лідери русинів обговорили 3 президентом Чехії «більшу автономію» українського Закарпаття. Paдіо Свобода. URL: https://www.radiosvoboda.org/a/zeman-i-rusyny/30157383.html. (Дата звернення: 5.04.2020)

24. Порошенко П. Про застереження владі ревізувати мовний закон. Facebook.

URL: https://www.facebook.com/petroporoshenko/photos/a.4744155526928 42/1974070169394032. (Дата звернення: 27.04.2020)

25. Посилення інформаційної години аналітикою, оновлені програми для нацменшин, співпраця із продакшенами: яким буде «UA: Закарпаття» у 2020 році. STV: Cуспільне. Detector_Media. URL: https://stv.detector.media/

reformuvannya/regional_movnyky/posilennya_informatsiynoi_godini_analit ikoyu_onovleni_programi_dlya_natsmenshin_spivpratsya_iz_prodakshenam i_yakim_bude_ua_zakarpattya_u_2020_rotsi. (Дата звернення: 5.04.2020)

26. Посол Угорщини обіцяє: Будапешт і надалі блокуватиме роботу форуму Україна-HATO. Главком. URL: https://glavcom.ua/country/ society/posol-ugorshchini-obicyaje-budapesht-i-nadali-blokuvatime-robotuforumu-ukrajina-nato-643159.html. (Дата звернення 26.03.2020)

27. Продюсер «Суспільного» на Закарпатті збирається пропагувати «русинство» всупереч фахівцям і Україні. Закарпаття онлайн. URL: https://zakarpattya.net.ua/News/199509-Prodiuser-Suspilnoho-naZakarpatti-zbyraietsia-propahuvaty-rusynstvo-vsuperech-fakhivtsiam-iUkraini. (Дата звернення: 5.04.2020) 
28. Рабінович відмовився виступати в Нацраді українською, що призвело до конфлікту. Інтерфакс. URL: https://www.ukrinform.ua/ rubric-society/2773831-rabinovic-vidmovivsa-vistupati-v-nacradiukrainskou-u-zasidanni-pererva.html. (Дата звернення: 25.04.2020)

29. Рабінович відмовився переходити на українську. Після зауваження Геращенко Разумков пригрозив вимикати мікрофон (ВІДЕО). Тексти.org.ua. URL: https://texty.org.ua/fragments/95819/ Rabinovych_vidmovyvsa_perehodyty_ na_ukrajinsku_Pisla_zauvazhenna95819. (Дата звернення: 21.04.2020)

30. Рабіновичу нагадали про необхідність виступати у Раді українською. Укрінформ. URL: https://www.ukrinform.ua/rubricpolytics/2773283-rabinovicu-nagadali-pro-neobhidnist-vistupati-u-radiukrainskou.html. (Дата звернення: 25.04.2020)

31. Разумков анонсував зміни до мовного закону. Главком. URL: https://glavcom.ua/news/razumkov-anonsuvav-zmini-do-movnogo-zakonu664832.html. (Дата звернення: 27.04.2020)

32. Разумков заявив, що Рада може переглянути закон про мовні квоти. Главком. URL: https://glavcom.ua/news/razumkov-zayaviv-shchorada-mozhe-pereglyanuti-zakon-pro-movni-kvoti-664820.html. (Дата звернення: 25.04.2020)

33. Регіональні радіостанції перевиконують мовні квоти Костинський. Укрінформ. URL: https://www.ukrinform.ua/rubricsociety/2874892-regionalni-radiostancii-perevikonuut-movni-kvotikostinskij.html. (Дата звернення: 22.04.2020)

34. Рішучий крок: Офіційний протест МЗС України проти угорської автономії на Закарпатті. Mukachevo.net. URL: http://www.mukachevo.net/ ua/news/view/658598. (Дата звернення: 12.04.2020)

35. Сидоренко С. Мовний закон штовхають до зміни: що рекомендує Україні Венеціанська комісія. Українська правда. URL: https://www.eurointegration.com.ua/articles/2019/12/6/7103953 (Дата звернення: 25.04.2020)

36. «Слуги народу» намагаються змінити закон про мову В'ятрович. Дивись.info. URL: https://dyvys.info/2020/03/17/slugy-narodunamagayutsya-zminyty-zakon-pro-movu-v-yatrovych (Дата звернення: 10.04.2020)

37. Совсун I. Реванш на марші: як «слуги народу» захищають російську мову, прикриваючись карантином. Украйнська правда. URL: https://www.pravda.com.ua/columns/2020/03/20/7244366. (Дата звернення: 10.04.2020)

38. Телеканал готовит к показу драматические и комедийные сериалы и заявляет о желании развивать предпраймовый слот. Телекритика. URL: https://telekritika.ua/smeh-i-slezy-kakie-plany-1-1-poproizvodstvu-kontenta-na-2020-god. (Дата звернення: 27.04.2020) 
39. У «Голосі» не розуміють, чому «мовні» і «освітні» зміни треба розглядати під час карантину. Укрінформ. https://www.ukrinform.ua/ rubric-polytics/2899203-u-golosi-ne-rozumiut-comu-movni-i-osvitni-zminitreba-rozgladati-pid-cas-karantinu.html. (Дата звернення: 20.04.2020)

40.У Росії схвалили закон про визнання українців і білорусів «носіями російської мови». Інформаиійне агентство «Украйнські Національні Новини». URL: https://www.unn.com.ua/uk/news/1857110-urosiyi-skhvalili-zakon-pro-viznannya-ukrayintsiv-i-bilorusiv-nosiyamirosiyskoyi-movi. (Дата звернення: 21.04.2020)

41. Угорщина передала МОН України свої пропозиції щодо навчання угорців на Закарпатті української мови. Закарпаття онлайн. URL: https://zakarpattya.net.ua/News/199343-Uhorshchyna-peredala-MONUkrainy-svoi-propozytsii-shchodo-navchannia-uhortsiv-na-Zakarpattiukrainskoi-movy. (Дата звернення: 5.04.2020)

42. Україна залишається без мовного омбудсмена: чому Тетяна Монахова вирішила звільнитися? OPINION UA. URL: https://opinionua.com/2020/04/24/ukraïna-zalishayetsya-bez-movnogoombudsmena-chomu-tetyana-monaxova-virishila-zvilnitisya. (Дата звернення: 27.04.2020)

43. Україна потребує нової методики викладання державної мови Макаров. Укрінформ. URL: https://www.ukrinform.ua/rubric-society/ 2881726-ukraina-potrebue-novoi-metodiki-vikladanna-derzavnoi-movimakarov.html. (Дата звернення: 27.04.2020)

44. Українська не для мелодрам? 1+1 втрапив у мовний скандал. BВC Україна. URL: https://www.bbc.com/ukrainian/51404360. (Дата звернення: 28.04.2020)

45. Уповноваженим із захисту державної мови обраний Тарас Кремінь - омбудсмен. Детектор медіа. URL: https://detector.media/ community/article/170468/2019-09-04-upovnovazhenim-iz-zakhistuderzhavnoi-movi-obranii-taras-kremin-ombudsmen (Дата звернення: 25.04.2020)

46. Уряд саботує мовний закон - Смолій. Агениія інформації та аналітики «Galinfo». URL: https://galinfo.com.ua/news/uryad_sabotuie_ movnyy_zakon_smoliy_328567.html. (Дата звернення: 25.03.2020)

47. Уряд створив Національну комісію зі стандартів державної мови. Урядовий портал. URL: https://www.kmu.gov.ua/news/uryad-stvorivnacionalnu-komisiyu-zi-standartiv-derzhavnoyi-movi. (Дата звернення: 25.04.2020)

48. Чергові спекуляції на тему утисків національних меншин регіону. Анонс Закарпаття. URL: http://anons-zak.com.ua/politika/ 28852-chergov-spekulyacyi-na-temu-utiskv-naconalnih-menshinregonu.html. (Дата звернення: 5.04.2020) 
49. Шумицька Г.В. Через діалог до взаєморозуміння в мультилінгвальному просторі: регіональна рецепція мовних новацій в освітній сфері. Монографія. Ужгород : Гражда, 2019. 104 с.

50. Шумицька Г., Путрашик В. Мовне законодавство України в проєкціях онлайнового медіапростору Закарпаття. Науковий вісник Ужсгородського університету. Серія: Філологія. 2019. Випуск 2 (42). C. 118-129. DOI:10.24144/ 2663-6840/ 2019.2(42).118-129.

51. Шумицька Г., Путрашик В. Мовне питання в Україні після висновків Венеційської комісії: закарпатський онлайновий медіаракурс. Таврійські філологічні наукові читання : Матеріали міжнародної науково-практичної конференції, м. Київ, 26-27 січня 2018 р. Київ : Таврійський національний університет імені В.І. Вернадського, 2018. C. $188-193$.

52. Шумицька Г., Путрашик В. Новинні сайти як індикатор мовної ситуації в Україні (на прикладі вебресурсів Закарпаття). Стиль і текст. Науковий збірник. 2017. Випуск 1 (17). С. 163-180.

53. Шумицька Г., Путрашик В. Реакція медіа на статтю 7 Закону «Про освіту» як віддзеркалення сучасної мовної ситуації в Україні (на матеріалах новинних веб-ресурсів Закарпаття). Науковий потенціал та перспективи розвитку філологічних наук : Матеріали міжнародної науково-практичної конференції, м. Київ, 8-9 грудня 2017 р. Київ : Таврійський національний університет імені В.І. Вернадського, 2017. C. $174-178$.

54. Якщо не вдасться скасувати Закон про мову, то «Слуги народу» підсилять його невиконання. Патріот Донбасу. URL: https://donpatriot.news/iakshcho-ne-vdastsia-skasuvaty-zakon-pro-movu-tosluhy-narodu-pidsyliat-joho-nevykonannia. (Дата звернення: 29.03.2020).

\section{Information about the authors:} Shumytska H. V., Candidate of Philology, Associate Professor at the Department of Journalism,

Dean of the Faculty of Philology Uzhhorod National University 3, Narodna Sq., Uzhhorod, 88000, Ukraine

Putrashyk V. I., Senior Teacher at the Department of Journalism, Chief Editor of the Mediacenter Uzhhorod National University 3, Narodna Sq., Uzhhorod, 88000, Ukraine 